\title{
Antimutagenic activity and identification of antioxidant compounds in the plant Poincianella bracteosa (Fabaceae)
}

\author{
Anna Catharina Feitosa Couto ${ }^{1}$, Irlana Karen de Pinho Araújo ${ }^{2}$, Alyne Pereira Lopes ${ }^{1}$, \\ Luciana Maria Fortes Magalhães Castelo Branco Couto ${ }^{1}$, Pedro Igor Barros Santos ${ }^{1}$, \\ Regina Maria Silva Sousa ${ }^{2}$, Maria Wlly da Silva Costa ${ }^{2}$, \\ Francisco Danilo Fernandes do Nascimento ${ }^{1}$, Maria das Dores Alves de Oliveira ${ }^{3}$, \\ Joaquim Soares da Costa Júnior ${ }^{3}$, Francielle Alline Martins ${ }^{2} \&$ Pedro Marcos Almeida $^{1 *}$ \\ 1. Department of Health, Universidade Estadual do Piauí, 64.049-570, Teresina - PI, Brazil; \\ annacatharina94@gmail.com, alyne-lopes1@hotmail.com, lucianafortesmagalhaes@hotmail.com, \\ pedroigor878@gmail.com, dannilosantoro@hotmail.com, pedromarcosalmeida@yahoo.com.br \\ 2. Department of Biology, Universidade Estadual do Piauí, 64.002-150, Teresina - PI, Brazil; irlanakaren@hotmail.com, \\ reginasousa484@gmail.com,wlly_silva@hotmail.com, franufv@yahoo.com.br \\ 3. Department of Chemistry, Instituto Federal do Piauí, 64053-390, Teresina, PI; maralves013@gmail.com, \\ jquimjr@gmail.com \\ * Correspondence
}

Received 02-VII-2018. Corrected 20-VI-2019. Accepted 04-IX-2019.

\begin{abstract}
Introduction: Poincianella bracteosa (Tul.) L.P. Queiroz. (Fabaceae), known as catingueira, is traditionally used in medicine to treat diarrhea, hepatitis and anemia. However, there are no studies on their toxicogenetic effects. Objective: The present study aimed to investigate the phytochemical profile as well as the mutagenic and antimutagenic potential of P. bracteosa aqueous bark extract in Allium cepa and Mus musculus. Methods: The extract from barks was diluted in distilled water to yield the four concentrations $(2,4,8$ and $16 \mathrm{mg} / \mathrm{ml})$ used in the $A$. cepa bioassay and the three doses $(10,20$ and $40 \mathrm{mg} / \mathrm{Kg})$ administered to the mice (five animals per group). The phytochemical profile was performed by the colorimetric test to identify the main secondary metabolites in the bark extract. After treatment, five-thousand meristematic cells were analyzed to determine the mitotic index, the mean number of chromosome alterations and the percentage of damage reduction. For mice, after 24, 48 and $72 \mathrm{~h}$, tail blood was collected from each animal for the preparation of two slides per animal. For each animal, 2000 normochromatic erythrocytes per mice were evaluated to establish the number of micronuclei and the protective effect. Data were analyzed by Kruskal-Wallis test $(\mathrm{P}<0.05)$. Results: The phytochemical analysis of the extract detected reducing sugars and tannins. None of the concentrations of extract was cytotoxic and the cytoprotective effect was observed in $A$. cepa for all treatments (pre-, simultaneous and post-). The total mean of chromosome alterations in all concentrations indicated a non-mutagenic activity of the bark. The percentage of damage reduction was observed in the pre- (77.6 to $90.5 \%$ ), simultaneous (95.6 to $114.7 \%$ ) and post- $(84.8$ to $117.7 \%$ ) treatments. In mice, none of the dosages of extract presented mutagenic effect and the percentage of damage reduction varied from -21.16 to $78.63 \%$ (pre-); from 27.51 to $101.28 \%$
\end{abstract}

Feitosa Couto, A. C., de Pinho Araújo, I. K. , Pereira Lopes, A., Fortes Magalhães, L. M., Branco Couto, C., Barros Santos, P. I., Silva Sousa, R. M., da Silva Costa, M. W., Fernandes do Nascimento, F. D., Alves de Oliveira, M. D., Soares da Costa Júnior, J., Martins, F. A., \& Almeida, P. M. (2019). Antimutagenic activity and identification of antioxidant compounds in the plant Poincianella bracteosa (Fabaceae). Revista de Biología Tropical, 67(6), 1103-1113. 
(simultaneous) and from 85.47 to $120.63 \%$ (post-treatment). Conclusions: Probably, the phytochemicals in the extract did not interfere with the cell cycle (A. cepa) nor caused damage to the DNA (A. cepa and mice), and exhibited protective effect in both studied species. The observed data indicate the importance of $P$. bracteosa bark extract for the inhibition of damage and chemoprevention. However, more studies should be carried out to ensure its protective effect on the genetic material.

Key words: Catingueira; chromosomal alterations; medicinal plant; micronuclei; chemoprevention.

Poincianella bracteosa (Tul.) L.P. Queiroz. (Fabaceae), popularly known as "catingueira", is a plant species endemic to the Brazilian Caatinga and Cerrado biomes (Queiroz, 2009). P. bracteosa has been widely used in popular medicine for different therapeutic purposes. Leaves and bark are used to treat catarrhal infections, diarrhea, gas, intestinal cramps, hepatitis and anemia (Monteiro, Souza, Lins Neto, Scopel, \& Trindade, 2014). Flowers are used to treat colds, flu and constipation (Castro \& Cavalcante, 2011). Phytochemical studies on $P$. bracteosa are incipient, having demonstrated the presence of tannins in the bark (Monteiro et al., 2014) and phenolic compounds (flavonoids, flavanones, tannins and xanthones), alkaloids and triterpenoids in the roots (Cruz et al., 2015). Tannins, saponins and reducing sugars were detected in the ethanolic leaf extract (Lopes et al., 2017) and tannins and reducing sugars were found in the aqueous bark extract (Pereira, et al., 2017).

The importance of antioxidative compounds, such as phenolic compounds, could be related to the inhibition of free radical formation (Rocha et al., 2016). In excess, these radicals may cause damage to the DNA, proteins, mitochondria and membranes, promoting alterations in cell structure and functions, and are therefore involved in pathologies, including cancer (Mendes, Costa, \& Mateus, 2015). Carcinogenesis may be related to toxicogenetic damage, which can be prevented with chemopreventive agents of plants, which are capable of reducing genotoxic and mutagenic events (Magosso et al., 2016). Antimutagenic agents may be classified as either desmutagenic or bio-antimutagenic. The first acts directly on the compounds that induce mutations in the DNA and bio-antimutagenic agents act mainly in the repair of DNA lesions (Rocha, et al., 2016).

Among the methods available to evaluate mutagenicity, the Allium cepa L. (onion) test is widely used because of its low cost, reliability and agreement with other mutagenicity investigation methods (Magosso et al., 2016). The micronucleus (MN) test in peripheral blood cells from in vivo models (mice) is also used for being simple, reliable, sensitive, inexpensive, and applicable to both in-vivo and in-vitro approaches (Araldi et al., 2015). The mentioned tests are widely used in the detection of clastogenic action (which promotes chromosomal breaks) and/or aneugenic effects (which induce aneuploidy or abnormal chromosomal segregation) (Bianchi, Fernandes, \& Marin-Morales, 2016).

Considering the ethnobotanical importance of $P$. bracteosa associated with the lack of toxicogenetic investigations with this plant, the present study aimed to analyze the phytochemical profile as well as the mutagenic and antimutagenic potential of the aqueous extract from barks of $P$. bracteosa in meristematic cells of $A$. cepa and in blood cells of mice.

\section{MATERIAL AND METHODS}

Biological Material: Barks of P. bracteosa were collected in Teresina, State of Piauí, Northeast of Brazil, in January 2016. Herbarium specimens containing leaves, flowers and fruits were stored at the Herbarium Afrânio Fernandes at the State University of Piauí (UESPI, Teresina, State of Piauí, Brazil; 
voucher specimen number HAF 03635). Seeds of $A$. сера cv. Vale Ouro IPA-11 used in the bioassays were kindly provided by the Agronomic Institute of Pernambuco (IPA, Recife State of Pernambuco, Brazil). Male Swiss mice (Mus musculus) were provided by the Central Vivarium of the Faculty of Medical Sciences (FACIME) at UESPI.

\section{Preparation of the bark extract from $P$.} bracteosa: Barks of P. bracteosa were dried in oven at $45{ }^{\circ} \mathrm{C}$ for 5 days in the Genetics Laboratory at FACIME, and subsequently ground in a blender to a fine powder. The aqueous extract was prepared with $20 \mathrm{~g}$ of the leaf powder diluted in $1 \mathrm{~L}$ distilled water, remaining boiling for $10 \mathrm{~min}$. The extract was then percolated through filter paper and stored at $4{ }^{\circ} \mathrm{C}$ for 24 $\mathrm{h}$ at a concentration of $20 \mathrm{mg} / \mathrm{ml}$. The aqueous extract from barks of $P$. bracteosa (AEBPb) was diluted in distilled water to yield the four concentrations $(2,4,8$ and $16 \mathrm{mg} / \mathrm{ml})$ used in the A. cepa bioassay and the three doses $(10,20$ and $40 \mathrm{mg} / \mathrm{Kg}$ ) administered to the test mice.

The concentrations applied to the plant cells in this study were based on satisfactory results using the somatic mutation and recombination test (SMART) in Drosophila melanogaster, in which the leaf extract had no mutagenic effect and showed antimutagenic activity (Lopes et al., 2017). Previous studies of the same research group in mice verified mutagenic action of the leaf extract at doses of 100, 200 and $400 \mathrm{mg} / \mathrm{Kg}$ (unpublished data). Thus, new doses $(10,20$ and $40 \mathrm{mg} / \mathrm{Kg}$ ) were adopted in the micronucleus assay with mice to assess mutagenicity and antimutagenicity. The difficulty in determining the test concentrations and/or dosages is due to the lack of studies on barks of $P$. bracteosa, owing to their solely empirical application by the population.

Tests for phytochemical investigation were performed at the Chemistry Laboratory of the Federal Institute of Piauí (IFPI) in Teresina (State of Piauí, Brazil) to detect the main primary and secondary metabolites (alkaloids, anthraquinones, saponins, phenols, tannins, reducing sugars, polysaccharides, proteins and amino acids, and catechins) present in $\mathrm{AEBPb}$, according to the protocol proposed by Barbosa et al. (2001). The tests were performed in triplicate.

DNA-damaging agents: Methyl methanesulfonate (MMS) (Sigma-Aldrich; CAS 66-27-3) was used to induce DNA damage in meristematic cells of $A$. серa. MMS $(10 \mu \mathrm{g} /$ $\mathrm{mL}$ ) is an alkylating agent with direct activity, inducing disturbances such as DNA breaks and bridges and chromosome loss, which are also expressed as micronuclei (Bianchi et al., 2016). In turn, the test mice were given cyclophosphamide (Sigma-Aldrich; C0768), a chemotherapy drug, at the dose of $50 \mathrm{mg} / \mathrm{Kg}$ body weight $(b w)$, administered intraperitoneally (ip). This drug is an alkylating compound with indirect action that is capable of establishing covalent bonds between base pairs of the DNA molecule and generating damage in the form of micronuclei (Fedel-Miyasato et al., 2014).

A. cepa test: Seedlings of $A$. серa were germinated at room temperature in Petri dishes containing filter paper moistened with distilled water, at the Genetics Laboratory of FACIME. Seeds with roots of approximately $2 \mathrm{~cm}$ in length were subjected to different treatments and protocols to evaluate mutagenicity and antimutagenicity, according to Fedel-Miyasato et al. (2014), with modifications.

To assess mutagenicity, seeds were transferred to the negative control (NC - distilled water), positive control (PC - $10 \mu \mathrm{g} / \mathrm{mL}$ MMS) and each concentration of $\mathrm{AEBPb}(2,4,8$ and $16 \mathrm{mg} / \mathrm{ml}$ ), with one dish for each control and concentration, for $24 \mathrm{~h}$. To evaluate antimutagenicity, three protocols were conducted using the DNA-damaging agent MMS. The following protocols were performed: pre-treatment to indicate preferential desmutagenic action; simultaneous treatment to assess both desmutagenic and bio-antimutagenic activity; and post-treatment to indicate bio-antimutagenic action (Fedel-Miyasato et al., 2014).

In the negative control, germinated seeds were grown for $48 \mathrm{~h}$ in distilled water. In the 
positive control (MMS), seeds were grown for $24 \mathrm{~h}$ in distilled water and for a further $24 \mathrm{~h}$ in aqueous MMS solution. In the pre-treatment, seeds were transferred to AEBPb $(2,4,8$ and $16 \mathrm{mg} / \mathrm{ml}$ ) for $24 \mathrm{~h}$, and to aqueous MMS for an additional $24 \mathrm{~h}$. In the simultaneous treatment, seeds were transferred to distilled water for $24 \mathrm{~h}$, then germinated for an additional $24 \mathrm{~h}$ in $\operatorname{AEBPb}(2,4,8$ and $16 \mathrm{mg} / \mathrm{ml})$ and MMS solution at the same time. In the posttreatment, seeds were grown in MMS for 24 $\mathrm{h}$ and germinated for an additional $24 \mathrm{~h}$ in $\operatorname{AEBPb}(2,4,8$ and $16 \mathrm{mg} / \mathrm{ml})$. After treatment, root tips were fixed in methanol/acetic acid solution $(3: 1)$ and stored at $-20{ }^{\circ} \mathrm{C}$ until slide preparation. Slides were mounted according to Almeida et al. (2016).

Mitotic index (MI), indicating cytotoxicity, and chromosome alterations (CA) were evaluated by scoring 5000 meristematic cells (experimental unit: slide with 500 cells, with a total of ten slides analyzed per treatment) under a light microscope (Olympus CX 21) at 400X magnification. Chromosome alterations arise from aneugenic (e.g. C-metaphases, chromosome adherence, lost chromosomes, multipolar anaphases and polyploid metaphases) or clastogenic (e.g. chromosome fragments and chromosome bridges) effects. Micronuclei may arise from both aneugenic or clastogenic effects. To determine the mitotic index, the number of cells in the different phases of mitosis (prophase, metaphase, anaphase and telophase) was divided by the total number of cells. To determine the total chromosome alterations, the total number of alterations was divided by the total number of cells.

Antimutagenic activity was assessed by analysis of the mean values for the $\mathrm{AEBPb}$ treatments compared to MMS, and by the percentage of damage reduction ( $\%$ DR). The $\%$ DR was calculated as the difference between the mean for positive controls and the mean number of damaged cells with combination, divided by the difference between damaged positive and negative control cells. The result was multiplied by 100 and expressed as the \% DR (Waters, Brady, Stack, \& Brockman, 1990).
Animal experiment: Male Swiss mice (M. musculus) at reproductive age, with an average body weight of $30 \mathrm{~g}$, were obtained from the Central Vivarium at FACIME. They were housed in a standard animal facility under controlled temperature $\left(22{ }^{\circ} \mathrm{C}\right)$ and photoperiod ( $12 \mathrm{~h}$ light, $12 \mathrm{~h}$ dark) with access to water and rodent chow ad libitum. All procedures and protocols followed the approved guidelines for the ethical treatment of animals, according to the Ethics Committee on the Use of Animals (CEUA) from the UESPI (Protocol 07557/15).

Mice were divided into five groups $(\mathrm{N}=5)$ to assess mutagenicity and 11 groups to assess antimutagenicity $(\mathrm{N}=5)$. The treatments and protocols were conducted according to FedelMiyasato et al. (2014) with modifications. To assess mutagenicity, distilled water $(0.1 \mathrm{~mL} / 10$ $\mathrm{g} b w$ via gavage) was administered to the mice, representing the NC. As PC, mice received cyclophosphamide $(50 \mathrm{mg} / \mathrm{Kg}, 0.1 \mathrm{~mL} / 10 \mathrm{~g}$ $b w$ ip). For the extract treatments, mice were given 10,20 or $40 \mathrm{mg} / \mathrm{Kg}$ AEBPb $(0.1 \mathrm{~mL} / 10$ $\mathrm{g} b w$ via gavage). Each group received the respective compound for $24 \mathrm{~h}$ of treatment for mutagenicity assessment.

To evaluate antimutagenicity in mice, three protocols were performed using the DNAdamaging agent cyclophosphamide. NC was administered to the mice on the first and second days. For PC, mice received distilled water on the first day and cyclophosphamide $(50 \mathrm{mg} /$ $\mathrm{Kg}$ ) on the second day. In the pre-treatment group, mice received $\mathrm{AEBPb}(10,20$ or $40 \mathrm{mg} /$ $\mathrm{Kg}$ ) on the first day and $50 \mathrm{mg} / \mathrm{Kg}$ of cyclophosphamide on the second day. In the simultaneous group, mice received distilled water on the first day and AEBPb $(10,20$ or $40 \mathrm{mg} / \mathrm{Kg})$ and $50 \mathrm{mg} / \mathrm{Kg}$ cyclophosphamide, simultaneously, on the second day. In the post-treatment, mice received $50 \mathrm{mg} / \mathrm{Kg}$ cyclophosphamide on the first day and AEBPb $(10,20$ or $40 \mathrm{mg} / \mathrm{Kg})$ on the second day. The \% DR was calculated as previously described (Waters et al., 1990).

For mutagenicity or antimutagenicity (micronucleus assay) evaluation, all experimental groups were subjected to peripheral blood collection at 24,48 and $72 \mathrm{~h}$ after the 
last administration of test compounds by puncturing the tail vein. Afterwards, mice were euthanized with twice the dose of ketamine $(100 \mathrm{mg} / \mathrm{Kg})$ and xylazine $(16 \mathrm{mg} / \mathrm{Kg})$. In order to evaluate mutagenicity and antimutagenicity in peripheral blood, the micronucleus assay was performed. Slides were mounted according to Fedel-Miyasato et al. (2014). To evaluate the presence of $\mathrm{MN}$ in each animal, a total of 2000 cells/mouse were analyzed using a light microscope (Olympus CX 21) at $1000 \mathrm{X}$ magnification.

Statistical analyses: In both bioassays, data were tested by the non-parametric Kruskal-Wallis test, followed by a posteriori Student-Newman-Keuls test $(\mathrm{P}<0.05)$ using the software BioEstat 5.3 (Ayres, Ayres, Ayres, \& Santos, 2007).

\section{RESULTS}

The phytochemical analysis of AEBPb detected reducing sugars and hydrolysable tannins. Regarding to toxicogenetic effects, none of the AEBPb concentrations (2, 4, 8 and 16 $\mathrm{mg} / \mathrm{ml}$ ) analyzed in meristematic cells of $A$. cepa demonstrated cytotoxic potential of the extract, as there was no significant difference in the mitotic index (MI) in relation to $\mathrm{NC}$ (Table 1). As to cytoprotective effect, the MI significantly increased in the pre- and posttreatments at all concentrations when compared to MMS (Table 1), whereas in the simultaneous treatment, only the lowest concentration had no cytoprotective effect (Table 1).

The total mean of chromosome alterations (CA) in all concentrations analyzed in A. cepa (Table 1) was not significant in comparison to $\mathrm{NC}$, indicating a non-mutagenic activity of the bark. When the CA were analyzed individually, none was significant at the evaluated concentrations (Table 2). The \% DR was observed at all concentrations in the pre- (77.6 to 90.5 $\%)$ and post- (84.8 to $117.7 \%$ ) treatments and in the three lowest concentrations of the simultaneous ( 95.6 to $114.7 \%$ ) treatment with a significant reduction in the total mean of $\mathrm{CA}$ when compared to MMS (Table 1). Overall, the majority of the CA in the pre-, simultaneous and post-treatments presented significant reductions when compared to MMS (Table 2).

In the bioassay using mice, none of the dosages $(10,20$ and $40 \mathrm{mg} / \mathrm{Kg})$ of AEBPb evaluated in the different collection periods $(24,48$ and $72 \mathrm{~h}$ ) presented a significant mutagenic effect (Table 3 ) in the blood cells in comparison to NC. The \% DR varied from -21.2 to $78.6 \%$ in the pre-treatment; from 27.5 to $101.3 \%$ in the simultaneous treatment; and from 85.5 to $120.6 \%$ in the post-treatment when compared to cyclophosphamide (Table 3 ).

\section{DISCUSSION}

Barks of $P$. bracteos $a$ are widely used in an empirical manner by the population for different therapeutic purposes (Castro \& Cavalcante, 2011; Monteiro et al., 2014). Nevertheless, given the lack of scientific information and studies concerning toxicogenetics of the species, two bioassays (A. cepa and mice) were employed in the present study to evaluate the effects of $\mathrm{AEBPb}$ on the ability of generating or repairing damage.

The MI of all AEBPb concentrations evaluated in meristematic cells of $A$. cepa did not show cytotoxic effect. Possibly, the phytochemicals (tannins and reducing sugars) detected in $\mathrm{AEBPb}$ did not interfere with the process of DNA synthesis or the blockade of the cell cycle in $\mathrm{G} 2$ phase, allowing cells enter the division process (Bianchi et al., 2016). Tannins and reducing sugars detected in the $\mathrm{AEBPb}$ have also been detected in the ethanolic leaf extract (Lopes et al., 2017) and in the aqueous extract of bark and leaves of P. bracteosa (Pereira et al., 2017). Monteiro et al. (2014) demonstrated the presence of tannins in the ethanolic bark extract. Moreover, Lopes et al. (2017) also found saponins in the ethanolic leaf extract, which were not detected in the present study.

In the protective effect protocol (pre-, simultaneous and post-treatment), the AEBPb demonstrates ability to modulate events so as to reduce the cytotoxicity of MMS, inhibiting 
TABLE 1

Mean of mitotic index, total chromosomal alterations and percentage of damage reduction (\% DR) in meristematic cells of $A$. cepa to evaluate mutagenicity and antimutagenicity (pre, simultaneous and post-treatment) after exposure to the aqueous extract from barks of $P$. bracteosa $(\mathrm{AEBPb})$ and to controls

\begin{tabular}{|c|c|c|c|}
\hline Treatment & Mitotic Index (Mean \pm SD) & Chromosomal Alteration (Mean \pm SD) & $\%$ DR \\
\hline \multicolumn{4}{|l|}{ Mutagenicity } \\
\hline $\mathrm{NC}^{1}$ & $294.4 \pm 12.8$ & $0.85 \pm 0.16$ & - \\
\hline $\mathrm{MMS}^{1}$ & $166.26 \pm 29.5^{*}$ & $28.75 \pm 4.83^{* *}$ & - \\
\hline $2 \mathrm{mg} / \mathrm{ml} \mathrm{AEBPb}$ & $297.3 \pm 15.8$ & $0.65 \pm 0.21$ & - \\
\hline $4 \mathrm{mg} / \mathrm{ml} \mathrm{AEBPb}$ & $296.5 \pm 17.8$ & $1.22 \pm 0.23$ & - \\
\hline $8 \mathrm{mg} / \mathrm{ml} \mathrm{AEBPb}$ & $265.4 \pm 10.5$ & $0.70 \pm 0.15$ & - \\
\hline 16 mg/ml AEBPb & $269.9 \pm 11.7$ & $0.76 \pm 0.10$ & - \\
\hline \multicolumn{4}{|l|}{ Antimutagenicity } \\
\hline $\mathrm{NC}^{2}$ & $259.65 \pm 42.81^{\#}$ & $2.18 \pm 0.34^{\# \#}$ & - \\
\hline $\mathrm{MMS}^{2}$ & $148.26 \pm 12.25$ & $10.27 \pm 1.21$ & - \\
\hline \multicolumn{4}{|l|}{ Pre-treatment } \\
\hline $2 \mathrm{mg} / \mathrm{ml} \mathrm{AEBPb}$ & $282.04 \pm 24.08^{\# \#}$ & $2.95 \pm 0.26^{\# \#}$ & 90.52 \\
\hline $4 \mathrm{mg} / \mathrm{ml} \mathrm{AEBPb}$ & $271.90 \pm 10.73^{\# \#}$ & $4.00 \pm 1.67^{\# \#}$ & 77.59 \\
\hline $8 \mathrm{mg} / \mathrm{ml} \mathrm{AEBPb}$ & $345.58 \pm 13.22^{\# \#}$ & $2.98 \pm 0.51^{\# \#}$ & 90.09 \\
\hline 16 mg/ml AEBPb & $327.12 \pm 12.19^{\# \#}$ & $3.39 \pm 1.03^{\# \#}$ & 85.04 \\
\hline $\mathrm{NC}^{3}$ & $249.65 \pm 22.81^{++}$ & $1.79 \pm 1.07^{++}$ & - \\
\hline $\mathrm{MMS}^{3}$ & $138.26 \pm 12.25$ & $9.36 \pm 1.47$ & - \\
\hline \multicolumn{4}{|l|}{ Simultaneous treatment } \\
\hline $2 \mathrm{mg} / \mathrm{ml} \mathrm{AEBPb}$ & $170.59 \pm 16.10$ & $1.09 \pm 0.52^{+}$ & 109.15 \\
\hline $4 \mathrm{mg} / \mathrm{ml} \mathrm{AEBPb}$ & $215.59 \pm 18.00^{++}$ & $0.44 \pm 0.25^{++}$ & 117.74 \\
\hline $8 \mathrm{mg} / \mathrm{ml} \mathrm{AEBPb}$ & $227.15 \pm 18.36^{++}$ & $2.51 \pm 0.29^{+}$ & 90.43 \\
\hline 16 mg/ml AEBPb & $226.19 \pm 28.90^{++}$ & $2.94 \pm 0.41$ & 84.76 \\
\hline \multicolumn{4}{|l|}{ Post-treatment } \\
\hline $2 \mathrm{mg} / \mathrm{ml} \mathrm{AEBPb}$ & $237.15 \pm 18.72^{++}$ & $1.91 \pm 0.51^{+}$ & 98.36 \\
\hline $4 \mathrm{mg} / \mathrm{ml} \mathrm{AEBPb}$ & $233.04 \pm 16.87^{++}$ & $2.12 \pm 0.93^{+}$ & 95.59 \\
\hline $8 \mathrm{mg} / \mathrm{ml} \mathrm{AEBPb}$ & $255.42 \pm 29.97^{++}$ & $0.68 \pm 0.11^{++}$ & 114.68 \\
\hline $16 \mathrm{mg} / \mathrm{ml} \mathrm{AEBPb}$ & $275.80 \pm 15.39^{++}$ & $1.67 \pm 1.02^{++}$ & 101.55 \\
\hline
\end{tabular}

1,2,3 NC: Negative control (Distilled water). ${ }^{1,2,3} \mathrm{MMS}$ : methyl methanesulfonate, $10 \mu \mathrm{g} / \mathrm{mL}$ (positive control). Pre-treatment: $24 \mathrm{~h} \mathrm{AEBPb}+24 \mathrm{~h}$ MMS. Simultaneous treatment: $24 \mathrm{~h}$ distilled water $+24 \mathrm{~h}$ of association of AEBPb and MMS. Posttreatment: $24 \mathrm{~h} \mathrm{MMS}+24 \mathrm{~h} \mathrm{AEBPb}$. SD: standard deviation. - (not applicable). ${ }^{*}$ Compared statistically with the $\mathrm{NC}^{1}$ to assess mutagenicity. ${ }^{\#}$ Compared statistically with the $\mathrm{MMS}^{2}$ to evaluate antimutagenicity (Pre-treatment). ${ }^{+} \mathrm{Compared}$ statistically with the $\mathrm{MMS}^{3}$ to evaluate antimutagenicity (Simultaneous and Post-treatment). ${ }^{* / \# /+}$ Significant by KruskalWallis test with a posteriori Student-Newman-Keuls test $(* / \# /+\mathrm{P}<0.05 ; * * / \# \# /++\mathrm{P}<0.01)$. The results refer to analysis of 5000 cells per treatment. 
TABLE 2

Mean of the types of chromosomal alterations in meristematic cells of $A$. cepa to evaluate mutagenicity and antimutagenicity (pre, simultaneous and post-treatment) after exposure to the aqueous extract from barks of $P$. bracteosa (AEBPb) and to controls

\begin{tabular}{|c|c|c|c|c|c|c|c|}
\hline \multirow{2}{*}{$\begin{array}{c}\text { Treatment } \\
\text { Mutagenicity }\end{array}$} & \multicolumn{7}{|c|}{ Chromosomal alteration $($ Mean \pm SD) } \\
\hline & CAd & $\mathrm{Cm}$ & $\mathrm{CL}$ & NB & $\mathrm{MN}$ & $\mathrm{CB}$ & $\mathrm{CF}$ \\
\hline $\mathrm{NC}^{1}$ & $0.0 \pm 0.0$ & $0.09 \pm 0.09$ & $0.31 \pm 0.10$ & $0.08 \pm 0.05$ & $0.08 \pm 0.07$ & $0.22 \pm 0.15$ & $0.0 \pm 0.0$ \\
\hline $\mathrm{MMS}^{1}$ & $1.71 \pm 0.82^{* *}$ & $0.10 \pm 0.10$ & $2.60 \pm 0.30^{*}$ & $0.48 \pm 0.15^{*}$ & $21.44 \pm 6.15^{* *}$ & $1.03 \pm 0.49^{*}$ & $1.40 \pm 0.50^{*}$ \\
\hline $2 \mathrm{mg} / \mathrm{mL} \mathrm{AEBPb}$ & $0.0 \pm 0.0$ & $0.05 \pm 0.04$ & $0.0 \pm 0.0$ & $0.05 \pm 0.03$ & $0.27 \pm 0.17$ & $0.24 \pm 0.14$ & $0.0 \pm 0.0$ \\
\hline $4 \mathrm{mg} / \mathrm{mL} \mathrm{AEBPb}$ & $0.03 \pm 0.09$ & $0.24 \pm 0.10$ & $0.48 \pm 0.22$ & $0.04 \pm 0.02$ & $0.10 \pm 0.10$ & $0.10 \pm 0.10$ & $0.0 \pm 0.0$ \\
\hline $8 \mathrm{mg} / \mathrm{mL} \mathrm{AEBPb}$ & $0.05 \pm 0.01$ & $0.14 \pm 0.05$ & $0.08 \pm 0.06$ & $0.00 \pm 0.00$ & $0.04 \pm 0.02$ & $0.23 \pm 0.15$ & $0.04 \pm 0.02$ \\
\hline $16 \mathrm{mg} / \mathrm{mL} \mathrm{AEBPb}$ & $0.0 \pm 0.0$ & $0.19 \pm 0.18$ & $0.05 \pm 0.05$ & $0.04 \pm 0.02$ & $0.00 \pm 0.00$ & $0.19 \pm 0.13$ & $0.04 \pm 0.02$ \\
\hline \multicolumn{8}{|l|}{ Antimutagenicity } \\
\hline $\mathrm{NC}^{2}$ & $0.40 \pm 0.13^{\# \#}$ & $0.32 \pm 0.17^{\# \#}$ & $0.28 \pm 0.11^{\#}$ & $0.34 \pm 0.16^{\# \#}$ & $0.33 \pm 0.19^{\# \#}$ & $0.21 \pm 0.19^{\# \#}$ & $0.31 \pm 0.16^{\# \#}$ \\
\hline $\mathrm{MMS}^{2}$ & $1.61 \pm 0.43$ & $1.05 \pm 0.31$ & $1.01 \pm 0.35$ & $2.22 \pm 0.18$ & $2.32 \pm 0.96$ & $0.86 \pm 0.22$ & $1.20 \pm 0.58$ \\
\hline \multicolumn{8}{|l|}{ Pre-treatment } \\
\hline $2 \mathrm{mg} / \mathrm{mL} \mathrm{AEBPb}$ & $0.35 \pm 0.10^{\#}$ & $0.37 \pm 0.24^{\# \#}$ & $0.21 \pm 0.15^{\# \#}$ & $0.35 \pm 0.10^{\# \#}$ & $1.32 \pm 0.41^{\#}$ & $0.05 \pm 0.05^{\# \#}$ & $0.30 \pm 0.12^{\# \#}$ \\
\hline $4 \mathrm{mg} / \mathrm{mL} \mathrm{AEBPb}$ & $0.55 \pm 0.28^{\# \#}$ & $0.40 \pm 0.24^{\#}$ & $0.19 \pm 0.14^{\# \#}$ & $1.18 \pm 0.13^{\#}$ & $0.98 \pm 0.58^{\# \#}$ & $0.26 \pm 0.16^{\# \#}$ & $0.45 \pm 0.41^{\# \#}$ \\
\hline $8 \mathrm{mg} / \mathrm{mL}$ AEBPb & $0.20 \pm 0.13^{\#}$ & $0.15 \pm 0.18^{\#}$ & $0.07 \pm 0.04^{\#}$ & $0.80 \pm 0.21^{\#}$ & $1.54 \pm 0.59$ & $0.07 \pm 0.06^{\# \#}$ & $0.16 \pm 0.09^{\# \#}$ \\
\hline $16 \mathrm{mg} / \mathrm{mL} \mathrm{AEBPb}$ & $0.26 \pm 0.24^{\# \#}$ & $0.20 \pm 0.20^{\# \#}$ & $0.16 \pm 0.15^{\# \#}$ & $0.52 \pm 0.26^{\# \#}$ & $1.98 \pm 0.56$ & $0.09 \pm 0.08^{\# \#}$ & $0.18 \pm 0.16^{\# \#}$ \\
\hline $\mathrm{NC}^{3}$ & $0.64 \pm 0.47^{+}$ & $0.10 \pm 0.11$ & $0.10 \pm 0.10^{+}$ & $0.09 \pm 0.08^{++}$ & $0.48 \pm 0.22^{++}$ & $0.18 \pm 0.17^{++}$ & $0.0 \pm 0.0^{++}$ \\
\hline $\mathrm{MMS}^{3}$ & $1.15 \pm 0.72$ & $0.08 \pm 0.05$ & $0.65 \pm 0.24$ & $0.46 \pm 0.17$ & $4.66 \pm 1.23$ & $1.56 \pm 0.42$ & $0.80 \pm 0.81$ \\
\hline \multicolumn{8}{|c|}{ Simultaneous treatment } \\
\hline $2 \mathrm{mg} / \mathrm{mL} \mathrm{AEBPb}$ & $0.0 \pm 0.0^{++}$ & $0.27 \pm 0.13$ & $0.27 \pm 0.14^{+}$ & $0.19 \pm 0.10^{+}$ & $0.27 \pm 0.13^{++}$ & $0.10 \pm 0.11^{++}$ & $0.0 \pm 0.0^{++}$ \\
\hline $4 \mathrm{mg} / \mathrm{mL} \mathrm{AEBPb}$ & $0.0 \pm 0.0^{++}$ & $0.10 \pm 0.11$ & $0.0 \pm 0.0^{++}$ & $0.0 \pm 0.0^{++}$ & $0.17 \pm 0.17^{++}$ & $0.09 \pm 0.09^{++}$ & $0.08 \pm 0.05^{+}$ \\
\hline $8 \mathrm{mg} / \mathrm{mL} \mathrm{AEBPb}$ & $0.75 \pm 0.39$ & $0.38 \pm 0.19$ & $0.0 \pm 0.0^{++}$ & $0.0 \pm 0.0^{++}$ & $0.83 \pm 0.21^{+}$ & $0.28 \pm 0.15^{+}$ & $0.09 \pm 0.09^{+}$ \\
\hline $16 \mathrm{mg} / \mathrm{mL}$ AEBPb & $0.48 \pm 0.68$ & $0.18 \pm 0.18$ & $0.0 \pm 0.0^{++}$ & $0.0 \pm 0.0^{++}$ & $2.11 \pm 0.63^{+}$ & $0.10 \pm 0.10^{++}$ & $0.0 \pm 0.0^{++}$ \\
\hline \multicolumn{8}{|l|}{ Post-treatment } \\
\hline $2 \mathrm{mg} / \mathrm{mL} \mathrm{AEBPb}$ & $0.0 \pm 0.0^{++}$ & $0.16 \pm 0.34$ & $0.16 \pm 0.15^{+}$ & $0.09 \pm 0.09^{++}$ & $0.89 \pm 0.74^{+}$ & $0.61 \pm 0.20$ & $0.0 \pm 0.0^{++}$ \\
\hline $4 \mathrm{mg} / \mathrm{mL} \mathrm{AEBPb}$ & $0.0 \pm 0.0^{++}$ & $0.29 \pm 046$ & $0.19 \pm 0.19^{+}$ & $0.0 \pm 0.0^{++}$ & $1.28 \pm 0.84^{+}$ & $0.18 \pm 0.18^{++}$ & $0.18 \pm 0.18^{+}$ \\
\hline $8 \mathrm{mg} / \mathrm{mL} \mathrm{AEBPb}$ & $0.0 \pm 0.0^{++}$ & $0.0 \pm 0.0$ & $0.24 \pm 0.11^{+}$ & $0.0 \pm 0.0^{++}$ & $0.25 \pm 0.11^{++}$ & $0.00 \pm 0.00^{++}$ & $0.09 \pm 0.07^{+}$ \\
\hline $16 \mathrm{mg} / \mathrm{mL} \mathrm{AEBPb}$ & $0.0 \pm 0.0^{++}$ & $0.18 \pm 0.38$ & $0.10 \pm 0.12^{++}$ & $0.0 \pm 0.0^{++}$ & $1.12 \pm 0.84^{++}$ & $0.18 \pm 0.18^{++}$ & $0.09 \pm 0.08^{+}$ \\
\hline
\end{tabular}

1,2,3 NC: Negative control (Distilled water). ${ }^{1,2,3} \mathrm{MMS}$ : methyl methanesulfonate, $10 \mu \mathrm{g} / \mathrm{ml}$ (positive control). Pre-treatment: $24 \mathrm{~h} \mathrm{AEBPb}+24 \mathrm{~h}$ MMS. Simultaneous treatment: $24 \mathrm{~h}$ distilled water $+24 \mathrm{~h}$ of association of AEBPb and MMS. Posttreatment: $24 \mathrm{~h} \mathrm{MMS} \mathrm{+} 24 \mathrm{~h} \mathrm{AEBPb}$. CAd: Chromosome adherence. Cm: C-metaphase. CL: Chromosome loss. NB: Nuclear bud. MN: Micronuclei. CB: Chromosome bridge. CF: Chromosome fragment. SD: standard deviation. - (not applicable). ${ }^{*}$ Compared statistically with the $\mathrm{NC}^{1}$ to assess mutagenicity. ${ }^{*}$ Compared statistically with the $\mathrm{MMS}^{2}$ to evaluate antimutagenicity (Pre-treatment). ${ }^{+}$Compared statistically with the $\mathrm{MMS}^{3}$ to evaluate antimutagenicity (Simultaneous and Post-treatment). ${ }^{* / \# /+}$ Significant by Kruskal-Wallis test with a posteriori Student-Newman-Keuls test $(* / \# /+1+0.05 ; * * / \# \# /++$ $\mathrm{P}<0.01)$. The results refer to analysis of 5000 cells per treatment. 
TABLE 3

Mean total and percentage of damage reduction (\% DR) related to tests for mutagenicity and antimutagenicity in micronucleus (MN) test in peripheral blood of Swiss male mice (Mus musculus)

\begin{tabular}{|c|c|c|c|c|c|c|}
\hline \multirow{2}{*}{ Treatment } & \multicolumn{3}{|c|}{ Micronucleus (Mean \pm SD) } & \multicolumn{3}{|c|}{$\% \mathrm{DR}$} \\
\hline & $24 \mathrm{~h}$ & $48 \mathrm{~h}$ & $72 \mathrm{~h}$ & $24 \mathrm{~h}$ & $48 \mathrm{~h}$ & $72 \mathrm{~h}$ \\
\hline \multicolumn{7}{|l|}{ Mutagenicity } \\
\hline $\mathrm{NC}^{1}$ & $9.30 \pm 7.12$ & $8.10 \pm 3.70$ & $7.10 \pm 2.38$ & - & - & - \\
\hline $\mathrm{PC}^{1}$ & $25.30 \pm 14.37^{*}$ & $31.60 \pm 9.77 * *$ & $19.30 \pm 5.87 * *$ & - & - & - \\
\hline $10 \mathrm{mg} / \mathrm{Kg}$ AEBPb & $9.70 \pm 3.27$ & $7.40 \pm 5.44$ & $8.20 \pm 2.78$ & - & - & - \\
\hline $20 \mathrm{mg} / \mathrm{Kg}$ AEBPb & $5.90 \pm 2.02$ & $5.10 \pm 3.87$ & $4.20 \pm 2.25$ & - & - & - \\
\hline $40 \mathrm{mg} / \mathrm{Kg}$ AEBPb & $4.70 \pm 1.34 *$ & $4.30 \pm 1.70$ & $3.90 \pm 1.20^{*}$ & - & - & - \\
\hline \multicolumn{7}{|l|}{ Antimutagenicity } \\
\hline $\mathrm{NC}^{2}$ & $6.20 \pm 4.71^{++}$ & $7.80 \pm 4.89^{+}$ & $8.20 \pm 5.20^{++}$ & - & - & - \\
\hline $\mathrm{PC}^{2}$ & $31.30 \pm 16.98$ & $26.70 \pm 17.08$ & $31.60 \pm 19.10$ & - & - & - \\
\hline \multicolumn{7}{|l|}{ Pre-treatment } \\
\hline 10 mg/Kg AEBPb & $24.90 \pm 6.54$ & $30.70 \pm 8.62$ & $17.30 \pm 3.47$ & 25.50 & -21.16 & 61.11 \\
\hline $20 \mathrm{mg} / \mathrm{Kg}$ AEBPb & $20.20 \pm 7.00$ & $20.50 \pm 5.34$ & $13.50 \pm 3.17^{+}$ & 44.22 & 32.80 & 77.35 \\
\hline $40 \mathrm{mg} / \mathrm{Kg} \mathrm{AEBPb}$ & $17.60 \pm 3.37$ & $15.90 \pm 3.35$ & $13.20 \pm 3.80^{+}$ & 54.58 & 57.14 & 78.63 \\
\hline \multicolumn{7}{|c|}{ Simultaneous treatment } \\
\hline 10 mg/Kg AEBPb & $21.80 \pm 10.33$ & $21.50 \pm 11.02$ & $16.40 \pm 8.03$ & 37.85 & 27.51 & 64.96 \\
\hline $20 \mathrm{mg} / \mathrm{Kg}$ AEBPb & $13.20 \pm 4.26^{+}$ & $16.70 \pm 5.46$ & $8.10 \pm 3.14^{++}$ & 72.11 & 52.91 & 100.43 \\
\hline $40 \mathrm{mg} / \mathrm{Kg} \mathrm{AEBPb}$ & $11.10 \pm 5.59^{++}$ & $9.10 \pm 2.60^{++}$ & $7.90 \pm 2.92^{++}$ & 80.48 & 93.12 & 101.28 \\
\hline \multicolumn{7}{|l|}{ Post-treatment } \\
\hline $10 \mathrm{mg} / \mathrm{Kg}$ AEBPb & $7.10 \pm 4.20^{++}$ & $5.70 \pm 4.47^{++}$ & $11.60 \pm 3.41^{+}$ & 96.41 & 111.11 & 85.47 \\
\hline $20 \mathrm{mg} / \mathrm{Kg}$ AEBPb & $5.00 \pm 2.16^{++}$ & $4.20 \pm 4.24^{++}$ & $8.90 \pm 4.56^{++}$ & 104.78 & 119.05 & 97.01 \\
\hline $40 \mathrm{mg} / \mathrm{Kg} \mathrm{AEBPb}$ & $4.20 \pm 3.22^{++}$ & $3.90 \pm 3.21^{++}$ & $7.10 \pm 3.35^{++}$ & 107.97 & 120.63 & 104.70 \\
\hline
\end{tabular}

1,2 NC: Negative control (Distilled water). ${ }^{1,2} \mathrm{PC}$ : Positive control (Cyclophosphamide, $50 \mathrm{mg} / \mathrm{Kg}$ ). AEBPb (aqueous extract from barks of P. bracteosa). Pre-treatment: $24 \mathrm{~h} \mathrm{AEBPb}+24 \mathrm{~h}$ PC. Simultaneous treatment: $24 \mathrm{~h}$ distilled water $+24 \mathrm{~h}$ of association of AEBPb and PC. Post-treatment: $24 \mathrm{~h} \mathrm{PC}+24 \mathrm{~h} \mathrm{AEBPb}$. SD: standard deviation. - (not applicable). ${ }^{*}$ Compared statistically with the $\mathrm{NC}$ to assess mutagenicity. ${ }^{+}$Compared statistically with the $\mathrm{PC}$ to evaluate antimutagenicity. ${ }^{* /+}$ Significant by Kruskal-Wallis test with $a$ posteriori Student-Newman-Keuls test $\left({ }^{* /+} \mathrm{P}<0.05 ;{ }^{* * /++} \mathrm{P}<0.01\right)$. The results refer to analysis of 10000 cells per treatment.

it directly and/or indirectly (Fedel-Miyasato et al., 2014). Probably, the tannins and/or reducing sugars of $\mathrm{AEBPb}$ neutralized the action of MMS through direct interaction with the mutagen. On the other hand, the phytochemicals of $\mathrm{AEBPb}$, known for their antioxidant activity (Rehman \& Khan, 2017), could neutralize the reactive oxygen species (ROS), resulting from MMS action (Tang et al., 2015), and therefore exert the cytoprotective effect. The accumulation of reactive oxygen species (ROS) may increase the risk of DNA damage, including the division of cells with unrepaired or misrepaired damage leading to mutations in meristematic cells of A. cepa (Kehrer \& Klotz, 2015). As a result, ROS may be associated with the decrease in MI observed in meristematic cells of $A$. cepa, which could lead to a delay in the mitotic cycle (Bianchi et al., 2016). Similar results with regard to cytoprotective effect were observed for barks of Poincianella pyramidalis (Silva et al., 2015), leaves of Rosmarinus 
officinalis (Felicidade et al., 2014) and Schinus terebinthifolius Raddi (Fedel-Miyasato et al., 2014), with presence of tannins and flavonoids (phenolic compounds), which are responsible for the antioxidant activity (Fedel-Miyasato et al., 2014).

The non-significance of the mean values for chromosome alterations (total or individual) obtained at the applied AEBPb concentrations demonstrates absence of aneugenic and/or clastogenic effects of the cited compounds (tannins and reducing sugars) in meristematic cells of $A$. cepa, not interfering with the processes of chromatin condensation, polymerization of spindle fibers and mitotic segregation (Bianchi et al., 2016). Moreover, the non-significant detection of chromosome loss, chromosome fragments, nuclear buds and/or chromosome bridges in the present study also corroborates the finding of non-significant mean values for $\mathrm{MN}$, as such structures arise from those chromosomal alterations (Almeida et al., 2016). In this way, the concentrations evaluated in the $A$. cepa test demonstrated that bark extract from $P$. bracteosa are not mutagenic.

In the bioassay with mice, the results did not indicate mutagenic effect at any of the dosages $(10,20$ and $40 \mathrm{mg} / \mathrm{Kg})$ evaluated at the different collection times. The results suggest that the phytochemicals (tannins and reducing sugars), as in A. cepa, did not promote chromosomal alterations of aneugenic and/or clastogenic origin (Magosso et al., 2016) that might originate $\mathrm{MN}$ in significant amounts in the normochromatic erythrocytes of the present study.

To evaluate the antimutagenicity in $A$. cepa and mice, three protocols were conducted using a DNA-damaging agent (MMS or cyclophosphamide). In the pre-treatment protocol (desmutagenic effect), a protective effect was detected at all evaluated concentrations in $A$. cepa. It is likely that the phytochemicals of $\mathrm{AEBPb}$ interacted with MMS, demonstrating the efficiency of AEBPb in adsorbing and/or chemically inactivating MMS as observed by Rocha et al. (2016) in cells of A. cepa. Howev$\mathrm{er}$, in mice, the protective effect (pre-treatment) was observed only at higher doses (20 and 40 $\mathrm{mg} / \mathrm{kg}$ ), indicating that the metabolism and bioavailability of AEBPb occurred more efficiently only after $72 \mathrm{~h}$. This result evidences that the phytochemicals of AEBPb also acted on the inhibition of mutagens arising from the metabolism of cyclophosphamide, inhibiting its uptake or blocking its interaction with the DNA (Araldi et al., 2015).

In the simultaneous treatment (desmutagenic and/or bio-antimutagenic effects), a protective effect was observed in most concentrations of $\mathrm{AEBPb}$ for $A$. cepa and dosages for mice of $\mathrm{AEBPb}$, reinforcing the interaction of the phytochemicals administered simultaneously with the damage-inducing agents (MMS or cyclophosphamide). To validate the bio-antimutagenic mode of action of AEBPb, the post-treatment protocol was used, which can indicate a chemoprotective activity. A protective effect was observed at all concentrations tested in A. cepa or dosages tested in mice, suggesting that the damage caused by MMS or cyclophosphamide was repaired by the phytochemicals of AEBPb. In this study, the significant reduction in all or most of the different chromosomal alterations (CA) in the antimutagenic assay ( $A$. cepa) in the three protocols reinforced that the phytochemicals of $\mathrm{AEBPb}$, possibly interacted with or suppressed the activity of MMS as also reported by FedelMiyasato et al. (2014).

In addition, in the pre- and simultaneous treatments, the lowest concentration ( 2 and 4 $\mathrm{mg} / \mathrm{ml}$ ) of the AEBPb showed the highest \% DR. Probably, increasing concentrations may be reducing the protective effect of AEBPb. This hypothesis is strengthened by FedelMiyasato et al. (2014) and Felicidade et al. (2014), who verified that higher concentrations of phenolic compounds found in S. terebinthifolius Raddi and Rosmarinus officinalis L. may have reduced the antioxidative activity, conferring decreased antimutagenicity to meristematic cells of $A$. cepa. While in the post-treatment, the opposite was observed, the highest \% DR was found in the highest concentrations (8 and $16 \mathrm{mg} / \mathrm{ml}$ ), which possibly stimulated the increase of enzymes involved in the repair of 
DNA lesions induced by MMS (bio-antimutagenic action). The reported results reinforce both modes of action (desmutagenic and bioantimutagenic) in A. cepa.

In mice, within each collection period, an increase in \% DR was verified with increasing concentrations of $\mathrm{AEBPb}$ in all evaluated protocols. In this way, the metabolization of $\mathrm{AEBPb}$ at higher concentrations resulted in greater bioavailability of the phytochemicals, not interfering with their antioxidant capacity. Additionally, it was observed, within each collection period, the highest \% DR in post-treatment.

In conclusion, the results of this study demonstrate that the phytochemicals of AEBPb possibly did not interfere with the progression of the cell cycle or the spindle fibers (aneugenic action), nor generate chromosome fragments (clastogenic action), indicating absence of cytotoxicity and mutagenicity in A. cepa. Similar results regarding the absence of mutagenicity were verified in mice. Our results demonstrate the important chemopreventive activity of $\mathrm{AEBPb}$, which is indirectly correlated with the prevention and/or treatment of diseases, such as cancer. Our findings further indicate that $\mathrm{AEBPb}$ can prevent and/or repair the DNA damage caused by chemotherapy agents by desmutagenesis and bio-mutagenesis and may therefore have therapeutic applications. However, complementary studies are required to elucidate the mechanisms of biochemical interaction of $\mathrm{AEBPb}$ with agents that induce DNA damage.

\section{ACKNOWLEDGMENT}

The authors thanked the scholarship grant program (PIBIC-UESPI) for financial support and Francisco Soares Santos-Filho for the botanical identification of the plant.

\section{RESUMEN}

Actividad antimutagénica e identificación de compuestos antioxidantes en la planta Poincianella bracteosa (Fabaceae). Introducción: Poincianella bracteosa
(Tul.) L.P. Queiroz. (Fabaceae), conocida como catinguei$r a$, es tradicionalmente utilizada en la medicina para tratar diarrea, hepatitis y anemia. Sin embargo, no hay estudios sobre los efectos tóxico genéticos de la $P$. bracteosa. Objetivo: En el presente estudio se tuvo como objetivo investigar el perfil fitoquímico y el potencial mutagénico y antimutagénico del extracto acuoso de la cáscara de $P$. bracteosa en Allium cepa y Mus musculus. Métodos: El extracto de la cáscara fue diluido en agua destilada para fornecer las cuatro concentraciones $(2,4,8$ y $16 \mathrm{mg} / \mathrm{ml})$ utilizadas en el bioensayo $A$. cepa y las tres dosis $(10,20 \mathrm{y}$ $40 \mathrm{mg} / \mathrm{Kg}$ ) fueron administradas a los ratones (5 animales por grupo). El perfil fito-químico fue realizado por el test colorimétrico para identificar los principales metabólitos secundarios en el extracto de la cáscara. Tras el tratamiento, 5000 células meristemáticas fueron analizadas para determinar el índice mitótico, el promedio de alteraciones cromosómicas y el porcentaje de reducción de daños. Para ratones, tras 24,48 y $72 \mathrm{~h}$, la sangre de la cola de cada animal fue recolectado para la preparación de dos láminas por animal. Para cada animal, 2000 eritrocitos normocromáticos por ratón fueron evaluados para establecer el número de micronúcleos y el efecto protector. Se analizaron los dados por el test de Kruskal-Wallis $(\mathrm{P}<0.05)$. El estudio fitoquímico del extracto detectó azúcares reductores y taninos. Resultados: Ninguna de las concentraciones del extracto fue citotóxica y en todos los tratamientos (pre, simultáneo y después) fue observado el efecto citoprotetor en A. cepa. El promedio total de las alteraciones cromosómicas en todas las concentraciones apuntó actividad no mutagénica de la cáscara. El porcentaje de reducción del daño fue observada en los tratamientos pre (de 77.6 al $90.5 \%$ ), simultáneo (del 95.6 al $114.7 \%$ ) y tras (de 84.8 al $117.7 \%$ ). En los ratones, ninguna de las dosis del extracto presentó efecto mutagénico y el porcentaje de reducción del daño osciló de -21.2 al $78.6 \%$ (pre); de 27.5 al $101.3 \%$ (simultánea) y de 85.5 al $120.6 \%$ (tras-tratamiento). Probablemente, los fito-químicos presentes en el extracto no interfirieron en el ciclo celular (A. cepa), tampoco causaron daños al DNA (A. cepa y ratones) y presentaron efecto protector en las dos especies estudiadas. Los datos observados apuntan la importancia del extracto de la cáscara de P. bracteosa para inhibición del daño y quimio prevención. Sin embargo, más estudios deben ser realizados para garantizar su efecto protector sobre el material genético.

Palabras clave: Catingueira; alteraciones cromosómicas; planta medicinal; micronúcleos; quimio prevención.

\section{REFERENCES}

Almeida, P. M., Araújo, S. S., Santos, I. R. M. R., MarinMorales, M. A., Benko-Iseppon, A. M., Santos, A. V., Randau, K. P., \& Brasileiro-Vidal, A. C. (2016). Genotoxic potential of leaf extracts of Jatropha gossypiifolia L. Genetics and Molecular Research, 15, 1-8. 
Araldi, R. P., Melo, T. C., Mendes, T. B., Sá Júnior, P. L., Nozima, B. H., Ito, E. T., Carvalho, R. F., Souza, E. B., \& Stocco, R. C. (2015). Using the comet and micronucleus assays for genotoxicity studies: A review. Biomedicine \& Pharmacotherapy, 72, 74-82.

Ayres, M., Ayres, J. M., Ayres, D. L., \& Santos, A. S. (2007). BioEstat 5.3 - aplicações estatísticas nas áreas das ciências biomédicas. Brazil: Sociedade Civil Mamirauá.

Barbosa, W. L. R., Quinard, E., Tavares, I. C. C., Pinto, L. N., Oliveira, F. Q., \& Oliveira, R. M. (2001). Manual para Análise Fitoquímica e Cromatográfica de Extratos Vegetais (Edição Revisada). Revista Científica da Universidade Federal do Pará, 4, 1-19.

Bianchi, J., Fernandes, T. C. C., \& Marin-Morales, M. A. (2016). Induction of mitotic and chromossomal abnormalities on Allium cepa cells by pesticides imidacloprid and sulfentrazone and the mixture of them. Chesmosphere, 144, 475-483.

Castro, A. S., \& Cavalcante, A. (2011). Caatinga Flowers. Brazil: Instituto Nacional do Semiárido.

Cruz, R. C. D., Carvalho, K. S., Silva, S. L. C., Gualberto, A. S., \& Macedo, G. E. L. (2015). Bioatividade da raiz de Poincianella bracteosa (Tul.) L.P. Queiroz (Fabaceae) sobre larvas do Aedes aegypti (Linnaeus, 1762) (Diptera: Culicidae). Revista Brasileira de Biociências, 13, 259-264.

Fedel-Miyasato, L. E. S., Formagio, A. S. N., Auharek, S. A., Kassuya, C. A. L., Navarro, S. D., Cunha-Laura, A. L., Monreal, A. C., Vieira, M. C., \& Oliveira, R. J. (2014). Antigenotoxic and antimutagenic effects of Schinus terebinthifolius Raddi in Allium cepa and Swiss mice: a comparative study. Genetics and Molecular Research, 13, 3411-3425.

Felicidade, I., Lima, J. D., Pesarini, J. R., Monreal, A. C. D., Mantovani, M. S., Ribeiro, L. R., \& Oliveira, R. J. (2014). Mutagenic and antimutagenic effects of crude hydroalcoholic extract of Rosemary (Rosmarinus Officinalis L.) on cultured meristematic cells Allium cepa. Vedic Research International - Phytomedicine, 2, 30-39.

Kehrer, J. P., \& Klotz, L. O. (2015). Free radicals and related reactive species as mediators of tissue injury and disease: implications for health. Critical Reviews in Toxicology, 45, 765-798.

Lopes, M. S. B., Sousa, R. M. S., Araújo, J. R. S., Costa Júnior, J. S., Santos Filho, F. S., Almeida, P. M., \& Martins, F. A. (2017). Efeito modulador das folhas de Poincianella bracteosa em células somáticas de Drosophila melanogaster. Revista Interdisciplinar Ciências e Saúde, 4, 285-288.
Magosso, M. F., Carvalho, P. C., Shneider, B. U., Pessatto, L. R., Pesarini, J. R., Silva, P. V., Correa, W. A., Kassuya, C. A., Muzzi, R. M., \& Oliveira, R. J. (2016). Acrocomia aculeata prevents toxicogenetic damage caused by the antitumor agent cyclophosphamide. Genetics and Molecular Research, 15, 1-14.

Mendes, V., Costa, V., \& Mateus, N. (2015). Involvement of the modulation of cancer cell redox status in the anti-tumoral effect of phenolic compounds. Royal Society of Chemistry Advances, 5, 1-9.

Monteiro, J. M., Souza, J. S. N., Lins Neto, E. M. F., Scopel, K., \& Trindade, E. F. (2014). Does total tannin content explain the use value of spontaneous medicinal plants from the Brazilian semi-arid region? Revista Brasileira de Farmacognosia, 24, 116-123.

Pereira, M. L., Couto, A. C. F., Siqueira, E. N., Ferraz, J. O. A., Oliveira, M. D. A., Martins, F. A., \& Almeida, P. M. (2017). Prospecção fitoquímica e potencial antimutagênico das cascas e folhas de Poincianella bracteosa (Tul.) L.P. Queiroz. Revista Interdisciplinar Ciências e Saúde, 4, 276-280.

Queiroz, L. P. (2009). Leguminosas da caatinga. Universidade Estadual de Feira de Santana, Royal Botanic Gardens, Kew (1st ed., 443 p.). Feira de Santana: Associação Plantas do Nordeste.

Rehman, S., \& Khan, H. (2017). Advances in antioxidant potential of natural alkaloids. Current Bioactive Compounds, 13, 101-108.

Rocha, R. S., Kassuya, C. A., Formagio, A. S., Mauro, M. O., Andrade-Silva, M., Monreal, A. C., CunhaLaura, A. L., Vieira, M. C., \& Oliveira, R. J. (2016). Analysis of the anti-inflammatory and chemopreventive potential and description of the antimutagenic mode of action of the Annona crassiflora methanolic extract. Journal Pharmaceutical Biology, 54, 35-47.

Silva, F. D. B., Sales, M. A. G., Sá, O. R. M., Santana, G. M., Deus, M. S. M., Sousa, J. M. C., Peron, A. P., \& Ferreira, P. M. P. (2015). Potencial citotóxico, genotóxico e citoprotetor de extratos aquosos de Caesalpinia pyramidalis Tul., Caesalpinia ferrea Mart. E Caesalpinia pulcherrima Sw. Revista Brasileira de Biociencias, 13, 101-109.

Tang, Z., Ding, W., Wang, L., Jiang, W., Zhang, Q., Chen, H., Zou, H., Dong, Y., Shao, J., \& Ma, T. (2015). Protective effect of vitamin E on methylmethanesulfonate-induced teratozoospermia in adult Sprague-Dawley rats. Molecular Medicine Reports, $12,4422-4426$.

Waters, M. D., Brady, A. L., Stack, H. F., \& Brockman, H. E. (1990). Antimutagenicity profiles for some model compounds. Mutation Research, 238, 57-85. 